\title{
DLBS1033 REDUCES BLOOD PRESSURE OF HYPERTENSIVE WISTAR-STRAIN RATS
}

\author{
Suryono \\ Faculty of Medicine, Jember University \\ Dr Soebandi Hospital, Jember
}

\begin{abstract}
ABSTRAK
Tujuan penelitian ini adalah untuk mengetahui efek DLBS1033 terhadap penurunan tekanan darah tikus galur wistar yang dibuat hipertensi. Jenis penelitian/design yang digunakan pada penelitian ini adalah desain eksperimen murni (true experimental design). Tempat Penelitian di Laboratorium Biomedik Fisiologi Fakultas Kedokteran Gigi Universitas Jember dan Laboratorium Farmasi Klinik dan Komunitas Fakultas Farmasi Universitas Jember. Subyek penelitian yang diambil adalah tikus wistar jantan berusia 2-3 bulan dengan berat $\pm 150-200$ gram sebanyak 22 ekor. Intervention sampel diinduksi menjadi hipertensi dengan memberikan obat prednison dosis $1,5 \mathrm{mg} / \mathrm{KgBB} / \mathrm{hari}$ peroral dan $\mathrm{NaCl} 2 \%$ dilanjutkan pemberian DLBS1033 0,5 gram/KgBB/hari peroral pada kelompok perlakuan. Hasil Uji T pada data tekanan darah sistolik didapatkan nilai $p=0,00$ yang berarti $p<0,05$, maka terdapat perbedaan yang signifikan pada tekanan darah sistolik kelompok perlakuan. Dapat disimpulkan bahwa DLBS1033 dapat menurunkan tekanan darah sistolik tikus wistar yang dibuat hipertensi dengan induksi prednison 1,5 mg/KgBB/hari dan NaCl $2 \%$.
\end{abstract} (FMI 2015;51:168-172)

Kata kunci : hipertensi, DLBS1033, lumbrokinase

\begin{abstract}
The purpose of this study was to determine the effects of DLBS1033 on blood pressure reduction in hypertension--induced wistar strain rats. Design used in this study was true experimental design. The study was conducted at Biomedical Laboratory, Physiology, Faculty of Dentistry, Jember University, and Clinical and Community Pharmacy Laboratory, Pharmacy Faculty, Jember University. Subjects were taken from male Wistar rats aged 2-3 months, weighing 150-200 grams, as many as 22 rats. Intervention samples were induced into hypertension by giving prednisone in a dose of $1.5 \mathrm{mg} / \mathrm{kg} /$ day orally and $2 \% \mathrm{NaCl}$ followed DLBS1033 of 0.5 grams/kgbw/day orally in the treatment group. T test results on systolic blood pressure $(p=0.00)$, which was $<0.05$, showing significant differences in systolic blood pressure in treatment groups. It can be concluded that DLBS1033 can lower systolic blood pressure in wistar rats with induced hypertension using prednisone $1.5 \mathrm{mg} / \mathrm{kgbw} /$ day and $\mathrm{NaCl} 2 \% .($ FMI 2015;51:168-172)
\end{abstract}

Keywords: hypertension, DLBS1033, lumbrokinase

Correspondence: Suryono, Faculty of Medicine, Universitas Jember, Dr. Soebandi Hospital, Jember, Indonesia. Email: suryonocardio@yahoo.com

\section{INTRODUCTION}

Hypertension is a serious health problem unresolved until today. The disease is known as the silent killer because of complications that involve critical organs (Rahajeng et al 2009). The prevalence of hypertension increases from year to year in both developing and developed countries. It is estimated that by 2025 the number will increase to $29.2 \%$ of the world population (Apriany 2012).

One of the pathophysiology of hypertension is the change in vascular structures. Animal studies shwoed that hypertension-induced rats with high salt intake can cause endothelial damage and abnormality occurs in blood vessel wall. Homeostasis can be overcome with stabilization and long-term antihypertensive therapy eg, ACE inhibitors (Humar et al 2009).
The existence of some side effects and oriental medicine that uses natural materials have encouraged people to choose alternative herbal medicine. Most people choose complementary medicine which combines the unconventional and conventional one (Yulianti 2006, Roeswim 2012). Herbal remedies have been widely accepted in almost all countries of the world. According to WHO, countries in Africa, Asia and Latin America use herbal medicine as a complement to primary treatment they receive. One standardized herbal medicine for the treatment of cardiovascular disease is DLBS1033. Lumbrokinase DLBS1033 is an enzyme extracted from earthworms Lumbricus rubellus by Dexa Laboratory of Biomolecular Sciences (DLBS) with the code 1033. 
Mihara et al succeeded in extracting lumbrokinase enzymes from the digestive tract of earthworms. Lumbrokinase is potential as fibrinolytic and antithrombotic in thrombosis incidence, such as myocardial infarction and stroke (Gayatri 2013). The incidence of thrombosis cannot be separated from hypercoagulable and prothrombotic increase. Patients with hypertension are found to be hypercoagulable and prothrombotic. Likewise, hypercoagulable and prothrombotic can trigger an increase in hypertension. It is therefore necessary to investigate the effect of DLBS1033 on the decrease of blood pressure in hypertensive-induced Wistar strain rats. The purpose of this study was to determine the effects of DLBS1033 on blood pressure reduction in hypertensive-induced wistar strain rats

\section{MATERIALS AND METHODS}

Design used in this study was true experimental design. The study was conducted in two sites, the Biomedical Laboratory of Physiology, Faculty of Dentistry, Jember University for mice maintenance, and Laboratory of Clinical Pharmacy and Community, Faculty of Pharmacy, Jember University, for examining rat blood pressure. The study was conducted in September and October, 2014.

Study population was a white Wistar-strain Rattus norvegicus rats. Samples were taken from male Wistar rats aged 2-3 months, weighing \pm 150-200 grams. Sample size in this study was 22 male Wistar rats divided into treatment and control groups, respectively comprising 11 rats. Samples were taken based on predetermined criteria. For a simple experimental study using experimental group and control group, the number of the members in each sample is between $10-20$.

The tools used in this study were stomach probes, blood pressure monitors for mice using tail-cuff method; rat cage, ohaus balance, mortar, pestle, and a measuring cup. Materials used for this study were DLBS1033 (Disolf®), $2 \% \mathrm{NaCl}, 5 \mathrm{mg}$ prednisone dosage, distilled water, animal feed, and husk for the experimental animals.
In this study, male Wistar rats were treated in the Laboratory of Biomedical Physiology, Faculty of Medicine, Jember University, and adapted for 1 week. Animals were fed standard and drank every day ad libitum and weighed and then grouped randomly by simple random sampling. Total group consisted of two groups comprising one control group and one treatment group in which the number of rats in each group was 11 rats. Group 1 was subjected to hypertension induction without treatment and group 2 to induced hypertension with treatment.

Rat blood pressure measurement was performed using non-invasive tail cuff method. Measurement of blood pressure was done before hypertension induction, after hypertension indction and after being given with the drug DLBS1033. For hypertension induction, rats in negative group and in the treatment group were given a combination of prednisone in a dose of $1.5 \mathrm{mg} / \mathrm{k}$ day and $2 \% \mathrm{NaCl}$ for 14 days after the initial blood pressure measurement.

For DLBS1033 therapy, the DLBS1033 with trademark "Disolf" was given for 8 days in the group treated with a dose of $0.5 \mathrm{~g} / \mathrm{KgBW} /$ day orally after hypertension induction and second blood pressure measurements. Data analysis used was comparative analysis using independent sample t-test with SPSS 21 software for Windows (Riwidikdo 2013). Differences were considered significant if $\mathrm{p}<0.05$.

\section{RESULTS}

Initial blood pressure measurement to determine normal or physiological blood pressure in rats was carried out on day 8 after acclimation for a week. For 1 days rats in control and treatment groups were equally induced to be hypertensive and blood pressure measurements were continued. After the blood pressure measurement, rats in treatment group were given with lumbrokinase for 8 days and the blood pressure was measured again after treatment. Blood pressure in control and treatment groups can be seen in Table 1. Data of average systolic and diastolic blood pressure in control and groups are illustrated in Figures 1 and 2).

Table 1. Mean blood pressure in control group

\begin{tabular}{|c|c|c|c|c|c|}
\hline \multicolumn{2}{|c|}{$\begin{array}{c}\text { Blood pressure } \\
\text { before hypertension induction } \\
\text { (Day1) }\end{array}$} & \multicolumn{2}{|c|}{$\begin{array}{c}\text { Blood pressure } \\
\text { after hypertension induction } \\
\text { (Day14) }\end{array}$} & \multicolumn{2}{|c|}{$\begin{array}{c}\text { Blood pressure } \\
\text { without DLBS1033 } \\
\text { (Day22) }\end{array}$} \\
\hline $\begin{array}{c}\mathrm{SBP} \\
(\mathrm{mmHg} \pm \mathrm{SD})\end{array}$ & $\begin{array}{c}\mathrm{DBP} \\
(\mathrm{mmHg} \pm \mathrm{SD})\end{array}$ & $\begin{array}{c}\mathrm{SBP} \\
(\mathrm{mmHg} \pm \mathrm{SD})\end{array}$ & $\begin{array}{c}\mathrm{DBP} \\
(\mathrm{mmHg} \pm \mathrm{SD})\end{array}$ & $\begin{array}{c}\mathrm{SBP} \\
(\mathrm{mmHg} \pm \mathrm{SD})\end{array}$ & $\begin{array}{c}\mathrm{DBP} \\
(\mathrm{mmHg} \pm \mathrm{SD})\end{array}$ \\
\hline $145 \pm 5.36$ & $80 \pm 0.27$ & $185 \pm 3.52$ & $80 \pm 0$ & $180 \pm 2.62$ & $80 \pm 0.31$ \\
\hline
\end{tabular}


Table 2. Mean blood pressure in treatment group

\begin{tabular}{|c|c|c|c|c|c|}
\hline \multicolumn{2}{|c|}{$\begin{array}{c}\text { Blood pressure } \\
\text { before hypertension induction } \\
\text { (Day1) }\end{array}$} & \multicolumn{2}{|c|}{$\begin{array}{c}\text { Blood pressure } \\
\text { after hypertension induction } \\
\text { (Day14) }\end{array}$} & \multicolumn{2}{|c|}{$\begin{array}{c}\text { Blood pressure } \\
\text { without DLBS1033 } \\
\text { (Day22) }\end{array}$} \\
\hline $\begin{array}{c}\text { SBP } \\
(\mathrm{mmHg} \pm \mathrm{SD})\end{array}$ & $\begin{array}{c}\mathrm{DBP} \\
(\mathrm{mmHg} \pm \mathrm{SD})\end{array}$ & $\begin{array}{c}\mathrm{SBP} \\
(\mathrm{mmHg} \pm \mathrm{SD})\end{array}$ & $\begin{array}{c}\mathrm{DBP} \\
(\mathrm{mmHg} \pm \mathrm{SD})\end{array}$ & $\begin{array}{c}\mathrm{SBP} \\
(\mathrm{mmHg} \pm \mathrm{SD})\end{array}$ & $\begin{array}{c}\mathrm{DBP} \\
(\mathrm{mmHg} \pm \mathrm{SD})\end{array}$ \\
\hline $145 \pm 9.47$ & $80 \pm 0.26$ & $187 \pm 3.72$ & $80 \pm 0.40$ & $159 \pm 2.86$ & $80 \pm 0.13$ \\
\hline
\end{tabular}

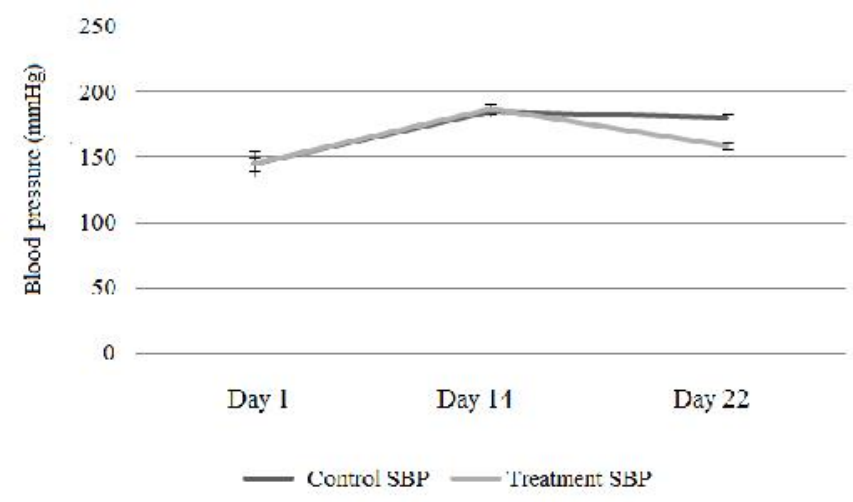

Figure 1. Systolic blood pressure in control and treatment groups

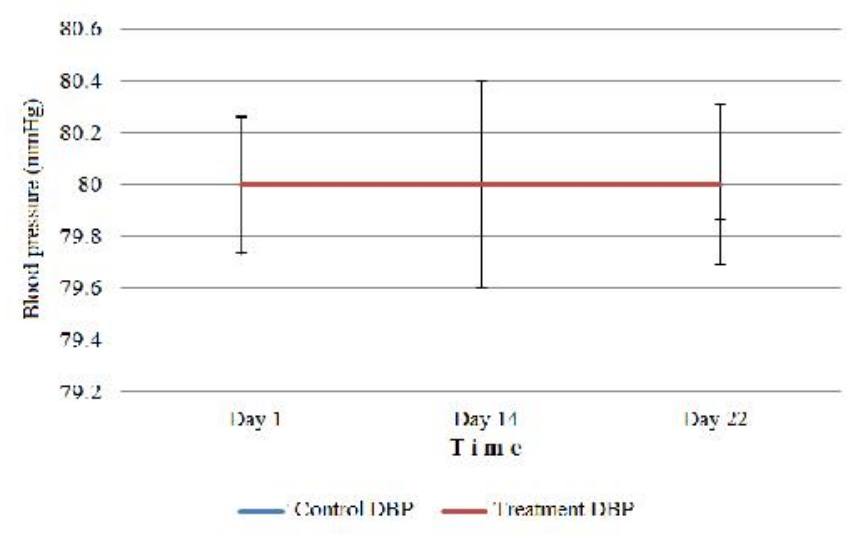

Figure 2. Diastolic blood pressure in control and treatment groups

From these data it can be seen that in control group systolic blood pressure before induction was averagely $145 \mathrm{mmHg}$ and diastolic blood pressure was averagely $80 \mathrm{mmHg}$. The blood pressure before hypertension induction was used as a reference for normal blood pressure in rats. After hypertension induction with prednisone and $\mathrm{NaCl}$ for 14 days, an increase of systolic blood pressure occurred as much as $185 \mathrm{mmHg}$, while diastolic increase did not occur. Mean diastolic pressure was $80 \mathrm{mmHg}$. Furthermore, control group was not given with the therapy with lumbrokinase for 8 days. The blood pressure of this group was measured, revealing mean systolic blood pressure of $180 \mathrm{mmHg}$ and diastolic blood pressure of $80 \mathrm{~mm} \mathrm{Hg}$.

In treatment group blood pressure measured before hypertension induction was referred as normal blood pressure in rats. Mean systolic blood pressure was 145 $\mathrm{mmHg}$ and a diastolic pressure $80 \mathrm{mmHg}$. After a 14day induced hypertension, the systolic blood pressure increased to $187 \mathrm{mmHg}$ and diastolic blood pressure did not increase, still averagely $80 \mathrm{mmHg}$. The data show tht in treatment group there was an increase in systolic pressure after hypertension induction.

Table 2 and Figure 1 in treatment group show that after the therapy was given for 8 days with DLBS1033 there was a decrease in systolic pressure by an average of 159 $\mathrm{mmHg}$ and a stable diastolic pressure of $80 \mathrm{mmHg}$.

According to the normal group, physiological blood pressure measured using a blood pressure measuring device used in this study showed an average of 145 $\mathrm{mmHg}$ for systolic blood pressure. As for hypertension, blood pressure measured using a blood pressure measuring device used in this study showed an average of 185 $\mathrm{mmHg}$ for systolic blood pressure. This value was different from the physiological systolic blood pressure of the rats, which was $100 \mathrm{mmHg}$. This is because of the calibration of different tools, so the blood pressure prior to the induction of hypertension was used as the base value (standard basic) in this study and also to see how much the increase and the decrease of the blood pressure. This means that the value of normal blood pressure referred to blood pressure values in control and treatment groups before hypertension induction and high blood pressure referred to blood pressure values ??after hypertension induction (increased blood pressure $>10 \mathrm{mmHg}$ of control's normal blood pressure before induction) (Badyal et al 2003). Diastolic blood pressure was not noticed because there was no significant difference in treatment and control group well after induction of hypertension as well as after the therapy. In addition, diastolic blood pressure range of $\pm 79-80$ 
$\mathrm{mmHg}$ was still a normal range. So, the systolic blood pressure is discussed more in this study.

Blood pressure data after treatment in each group were analyzed using independent sample t-test. Test $\mathrm{T}$ was regarded as significant if $p<0.05$. After testing $T$ in systolic blood pressure data, $\mathrm{p}$ value $=0.00$ was obtained, which was $<0.05$, showing significant differences in systolic blood pressure in treatment group and systolic blood pressure in control group after treatment.

Diastolic blood pressure data were also subjected to $t$ test. $T$ test was regarded as significant if $p<0.05$. After carrying out $\mathrm{t}$ test in diastolic blood pressure data, the $\mathrm{p}$ value obtained was $0.329 \quad(p>0.05)$, showing no significant difference in diastolic blood pressure between treatment and control groups after treatment.

Based on the results of statistical data analysis in this study, DLBS1033 drug therapy in hypertensive rats models of could lower systolic blood pressure significantly, but did not provide significant change in diastolic blood pressure.

\section{DISCUSSION}

This study aims to determine whether DLBS1033 therapy can lower blood pressure in Wistar rats which were induced to become hypertensive by the induction of prednisone and $\mathrm{NaCl}$. This study used 22 male Wistar strain rats weighing as determined and were divided into 2 groups. The first group was the control group (induced hypertension without receiving DLBS1033 therapy) and the second group was the group receiving treatment with DLBS1033 in a dose of $0.5 \mathrm{~g} / \mathrm{kg} /$ day for 8 days after hypertension induction for 14 days. Samples used from the beginning of the study were 22 rats with an additional reserve of 1 rat for each group. Thus, the total number was 24 rats. However, at the time of acclimatization for 7 days two mice died of illness before treatment so these mice were not included in the criteria of the sample to be studied.

Hypertensive condition showed abnormalities in blood vessel walls (endothelial dysfunction or endothelial cell damage), abnormalities of homeostasis factors, platelets, and fibrinolysis which was suspected as hypertension that can lead to a prothrombotic and hypercoagulation that are progressively more severe and damaging the target organ. Therefore, through the mechanism of DLBS1033 as thrombolytic and fibrinolytic, DLBS1033 can hydrolyze fibrin rich in plasminogen, and fibrin-free plasminogen, so it can be concluded that DLBS1033 works as a stimulant plasminogen and also can digest fibrin, which would directly inhibit hypertension progressivity and reduce blood pressure (Mihara et al 1991).

DLBS1033 can also inhibit PDE III, resulting in increased c-AMP and the inhibition of $\mathrm{Ca} 2+$ transport. The inhibition of calcium ions flow in the L-type channels will decrease in intracellular calcium levels, resulting in relaxation of the blood vessel wall that gives the effect of a decrease in blood pressure (Gayatri 2013). The results of the blood pressure data is the significant decrease in systolic blood pressure under the influence of DLBS1033 therapy at a dose of 0.5 $\mathrm{g} / \mathrm{kg} / \mathrm{day}$. Based on the data that has been presented, two groups with hypertension-induction had an increase in systolic blood pressure in an average of $185 \pm 187 \mathrm{mmHg}$ Then, the treatment group receiving DLBS1033 had decreased mean systolic blood pressure of $\pm 159 \mathrm{mmHg}$. However, there was no change in diastolic blood pressure both at initial measurement of blood pressure, hypertension and after the post-induction DLBS1033 therapy between control and treatment group, so there was no significant difference.

\section{CONCLUSION}

DLBS1033 derived from the extract of Lumbricus rubellus gastrointestinal tract can lower systolic blood pressure of wistar rats ratrs with hypertension induced with $1.5 \mathrm{mg}$ prednisone/kgBW/day and $2 \% \mathrm{NaCl}$.

\section{REFERENCES}

Apriany, R. E. 2012. Asupan Protein, Lemak Jenuh, Natrium, Serat Dan IMT Terkait Dengan Tekanan Darah Pasien Hipertensi Di RSUD TUGUREJO SEMARANG. Journal of Nutrition College, 700-714.

Badyal D.K, H.Lata, dan A.P. Dadhich. 2003. Animal Models of Hypertension and Effect of Drugs. Indian J. of Pharmacology, Vol. 35 : 349-362.

Gayatri, Anggi Purwantyastuti. 2013. Penggunaan Lumbrokinase sebagai Fibrinolitik dan Antitrombotik Oral. [Online], Vol 40 (3), 4 halaman. Tersedia: http://www.kalbemed.com [17 Juli 2014].

Gray, et al. 2005. Lecture Notes Kardiologi Edisi 4. Jakarta: Erlangga Medical Series

Humar, R, L.Zimmerli, dan E. Battegay. 2009. Angiogenesis and Hypertension : an update. Journal of Human Hypertension Division and Research Unit of Internal Medicine, University, Zurich Switzerland, Vol. 23 : 773-782.

Mihara, H., et al. 1991. A Novel Fibrimolitic Enzime Extracted from the Earthworm, Lumbricus rubellus. Japanese J. Physicol. 41: 461-472. 
Rahajeng, Ekowati dan Sulistyowati Tuminah. 2009. Prevalensi Hipertensi dan Determinannya di Indonesia. [Online]. Vol.39 : 12, 8 halaman.Tersedia: http://indonesia.digitaljournals.org/index.php/idnmed/ article/download/700/699 [10 September 2014].

Riwidikdo, Handoko. 2013. Statistika Kesehatan ( Dengan Aplikasi SPSS dalam Prosedur Penelitian ). Makassar : Mitra Cendekia.
Roeswim, Anna P. 2012. Antihypertensive Effect of Brucea javanica (L.) Merr. Fruit Extract. Makara Journal of Science, 71-76.

Yulianti, Sufrida. 2006. 30 Ramuan Penakluk Hipertensi. Jakarta : Agro Media Pustaka. 